\title{
A timely wakeup call: The end of theology as Science
}

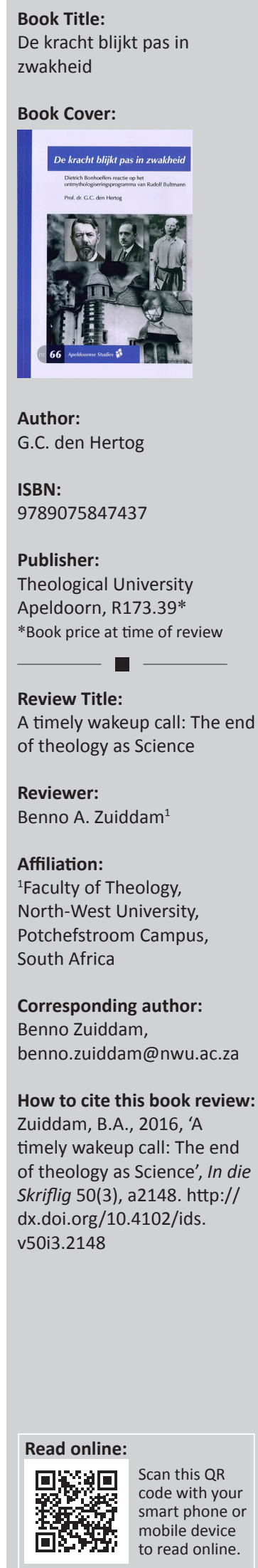

In De kracht blijkt pas in zwakheid [Strength revealed in weakness], Prof G.C. den Hertog of the Theological University Apeldoorn responds to a preliminary report of the Royal Netherlands Academy of Science 'Ready for Change' on the future of theology and religious studies in the Netherlands. Within the parameters of this new approach, propositional revelation is no longer a valid basis for science. Consequently, theology will no longer be allowed to claim true pronouncements about God, but will only be allowed to evaluate human religious thinking in a horizontal way. Den Hertog refers to Bultmann's call to demythologise the Bible (1941) as similar development in Germany, and seeks to find a solution in Bonhoeffer's response to Bultmann. It is aimed at students and educators in the field of theology.

This is a timely publication that leaves reformed theologians under no illusion of the secular standards that are presently being forced on theology as a science. These pressures are not only felt in the Netherlands, but real and present dangers exist in almost every Western country, particularly since the neo-liberal overhaul of all tertiary education in the last 20 years, where results are no longer valued spiritually and culturally, but reduced to their economic merit and contribution to liberal democracy. In other words, it needs to make money and have measurable humanistic outcomes. This is indeed a far cry from Christian civilisation, which has always maintained theology as the science for metaphysical truth, based on God's reliable propositional revelation in Scripture. The humanities and natural sciences were, in that view, complementary and were caught under the general umbrella of philosophy. As faith in prepositional revelation as objectively accessible truth is declined in the Netherlands and other Western countries, several faculties of theology were forced to close down or to amalgamate with departments of religious studies. For all practical intents and purposes the preposition that all religion is manmade and therefore really part of the humanities, prevails. This puts a lot of pressure on institutions like the University of Apeldoorn (pp. 8-9) who are committed to a classical reformed approach to theology in the literal sense, namely that truth about God is scientifically accessible through God's revelation by Word and Spirit.

Following Heidegger's man centred existential philosophy, Bultmann set out to scrape away all alleged layers of mythology from the New Testament, which in effect left him with a mere human Jesus as a Jewish rabbi who lived and taught for a while and then died. No miracles, no supernatural knowledge, no exorcisms and no bodily resurrection - only spiritual principles and internal religious feelings that operate in the here and now of our personal consciousness.

Like Bultmann, Bonhoeffer was also part of the Bekennende Kirche. It is important to note that he shared Bultmann's view of Scripture as an unscientific text with a mythological worldview. Bonhoeffer, however, wanted to preserve the belief that some truths, mainly centred around the Lutheran core doctrines are accessible for everyone - not scientifically, but by a leap of faith and emotional or spiritual relationship with God when reason has reached a dead end. This Offenbarungspositivismus allowed for proclamation of the gospel in Church and State and functioned as a hermeneutical basis for testimony against Nazi Germany.

The important question is whether Bonhoeffer's alternative is very much different from Bultmann's. Does he really offer a viable solution that preserves the integrity of classical theology? Den Hertog thinks so and commends Bonhoeffer's spirit of willingness to obey Christ, particularly in his prison years (Widerstand und Ergebung) to theological students today.

Although Den Hertog aims positively at avoiding 'heartless' formalised theology, which lacks a relationship with God, this also leads him to claim that 'the articles of the Christian faith have no metaphysical or even mythological thought-contents', but should on the contrary be characterised as promises aimed at the human heart (p. 60). This statement runs the risk of denying objective and propositional truth to the articles of the catholic and apostolic faith as well as implicitly to the

Copyright: () 2016. The Authors. Licensee: AOSIS. This work is licensed under the Creative Commons Attribution License. 
Scriptures. Particularly the creeds concerning the nature of Christ and the Holy Trinity reflect metaphysical thought contents. Are rational faith contents separable from a living relationship with Christ (p. 61)? Is it true that 'whosoever honestly practices Theology never knows where he or she will end up' (p. 60)? In this approach, human rational experience easily takes over as criterion for preservation and relevance. Indeed, truth must be internalised by God, but his is not a mere mystical voice. Whoever honestly practices theology as a confessing Christian, willingly and a priori subjects his intellect to God's revelation in Scripture and to the articles of the Christian faith.

One should not forget that despite its emotional calls for intellectual honesty and obedience to Christ, the 'Bonhoefferian' approach effectively surrenders the traditional basis of both reformed and traditional catholic exegesis to an existentialistic, man centred paradigm where Sacra Scriptura sui ipsius interpres is no longer a valid scientific attitude and principle. That Den Hertog's approach is also vulnerable in this regard, is suggested by his view that 'a formalised hermeneutics is not an accessible way and rather invites avoiding, silence and unconscious growing away from the credo of the Church' (p. 61). Still, it was this same lack of formalised hermeneutics that allowed Bonhoeffer to opt for an assassination plot, when this seemed a more practical solution than the Sermon on the Mount. Religious will and emotion are indispensable, but as a compass they have been found wanting.

For classical theology the doctrine of Scripture and reliable propositional revelation is a sine qua non. As is the apostolic injunction: 'without faith it is impossible to please God' (Heb 11:6). If theology in its true meaning is to survive as a science at all, these should be equally yoked. 